\title{
RISK ESTIMATION WITH THE APPLICATION OF THE MATRIX METHOD DURING THE OPERATION OF THE FORKLIFT
}

doi:10.2478/czoto-2021-0036

Date of submission of the article to the Editor: 29/11/2020

Date of acceptance of the article by the Editor: 3/04/2021

\author{
Monika Kozińska ${ }^{1}$ \\ Norbert Radek ${ }^{1}$ - orcid id:0000-0002-1587-1074 \\ Andrzej Rozlach ${ }^{2}$ \\ Magdalena Mazur ${ }^{3}$ - orcid id:0000-0003-3515-8302 \\ ${ }^{1}$ Rzeszow University of Technology, Poland \\ 2Office of Technical Inspection, branch in Kielce, Poland \\ ${ }^{3}$ Czestochowa University of Technology, Poland
}

\begin{abstract}
The paper presents issues related to the analysis of the position of a forklift operator.Hazards at the workplace were presented and risk estimation was carried out using the matrix method on the position of a forklift operator. The risk assessment using the matrix method was performed in accordance with the PN-N-18002: 2011 standard. The hazards at the forklift operator's workplace were identified and the occupational risk was assessed. In addition, the employee's personal protective equipment and security factors are also presented, which have been defined to increase the safety of work with forklifts.
\end{abstract}

Keywords:matrix method, risk estimation, forklift, operation

\section{INTRODUCTION}

One of the most popular in-plant transport devices is a forklift truck. It is the basic equipment of every enterprise or warehouse. Forklifts are also used by individuals for whom this device is an essential "tool" of work. In today's world, it is difficult to observe that a workplace does not have forklifts, which is a basic feature proving their universality. Its main advantages are, among others: ease of use, ergonomics and economical use of warehouse / plant space. Despite the advantages that have been presented, it is the safety behavior during the operation of the forklift that is not at the proper level, which has negative consequences. Often the cause of accidents involving these devices is haste, lack of attention or disregard of health and safety regulations by the forklift operator and other employees. In order to counteract such events, it is necessary to: make employees aware of the possible consequences of not following internal safety procedures, OHS instructions, lack of supervision and the occupational risk of working with a forklift (Klimecka-Tatar et al., 2016; Koradecka, 2008; Rączkowski, 2020). 
Forklifts, or rather forklift trucks, belong to the group of in-house transport devices, they are the most popular vehicles in this group. They are mainly used in activities related to unloading or reloading of products, and they are also used to arrange and organize materials in warehouses. These small-sized motor vehicles significantly facilitate the transport and handling of relatively heavy goods. They are an appropriate device to replace, if spatially possible, manual transport, which is a very heavy physical burden for employees, and is often impossible due to the strength of human muscles. Therefore, forklifts have found wide application in factories. They are used almost everywhere where it is possible, from a large industrial plant through largearea shops to households. The goods are usually transported on wooden pallets specially adapted for transport with forklifts, which are placed on the forks of the truck. The characteristics of the forklift mainly depend on the work intended for it. The choice of the forklift model is adapted to the operating conditions, e.g. to the storage height or to the length and possible width of communication routes. These can be forklifts designed only to work outdoors, but also intended for working inside the building (Prochowski et al., 2009).

\section{OCCUPATIONAL HAZARD}

Every profession and work performed in all types of workstations is not in $100 \%$ safe. There are always some dangers, sometimes to a lesser degree, but often to a very large extent, it depends on the nature of the activities performed at the workplace. The employer is obliged to ensure work safety for his workers, or has a low risk of work hazard (Brown et al., 2021). It is he who must take care of the safety and health protection of each of the employees performing their work and the duties belonging to it. In order for the employer to be able to fulfill his obligation, it is necessary to analyze the current state of safety, as well as all other possible elements of the work environment that significantly affect the state of safety at the workplace. The purpose of proper noticing and identification of threats and estimating the level of safety is to perform occupational risk assessment. After carrying out such an assessment, the employer will be able to take appropriate actions and efforts to improve the safety and protection of employees (Jabłoński et al. 2014; Kapustka et al., 2020).

Occupational risk at work is defined as a possible disadvantage, related to activities performed during operation events that may cause loss. The result of these factors is a negative impact on the health of employees, which results from the occupational hazards in the work environment or the nature of the work performed by the employee. (PN-N-18002:2011; Woźny 2020; Woźny et al., 2015).

The purpose of occupational risk assessment is to ensure the safety and protection of employees at work. However, it is only possible by eliminating the existing threats or reducing the level of threats that are currently not completely removable. It is carried out in such a way that:

- $\quad$ Assess and define the level of admissibility of occupational risk, previously detected threats and apply protection measures that are required by law,

- $\quad$ Analyze the correct selection of protection measures against current threats that are present in the workplace,

- Determine the order of priorities, if required, in activities aimed at elimination or reduction of occupational risk in the workplace,

- $\quad$ Present to employees, including / or employee representatives, as well as supervisory and control institutions that hazards in the workplace have 
been identified. They have been eliminated and / or reduced through the use of appropriate protection measures, and thus the associated occupational risk has also been reduced and / or eliminated,

- The equipment of workstations, its organization and materials were adequately adapted to the psychophysical abilities of employees,

- Ensure the increase in the safety and health of employees through the proper use of collective and individual protection equipment, as well as by making appropriate changes in the field of technology, methods and work organization (PN-N-18002:2011).

Occupational risk assessment mainly involves regular monitoring and testing of all elements of the work. These activities are designed to look for connections with threats that could have an impact on undesirable situations, diseases and negative well-being. These actions also determine if the detected threats can be removed. if this is not possible, appropriate security equipment should be used (PN-N18002:2011; Szlązak et al., 2010; Ulewicz et al., 2015).

\section{RISK ASSESSMENT - MATRIX METHOD}

The occupational risk assessment according to the matrix method is presented in the PN-N-18001: 2011 standard. It is an inductive method that is used for the qualitative estimation of occupational risk in the workplace. The occurrence of an accident and qualitatively estimated risk parameters are the assumptions of this method. Two approaches to determining risk parameters are used in this method: the severity of the consequences, i.e. the effects, and the probability of certain consequences (Romanowska-Słomka et al., 2008; Matuszewska et al., 2016).

The matrix method is prepared on the basis of the following steps, which indicate that (Romanowska-Słomka et al., 2008):

- The risk assessment is carried out within the defined boundaries of the facility,

- The threats are listed in a properly prepared report,

- The risk was estimated based on the determination of possible consequences, as well as the probability of their occurrence,

- $\quad$ Risk evaluation is done by obtaining values from a matrix.

The classification of risk parameters using the matrix method is carried out on the basis of three levels: small, medium and large, or based on a five-step scale, at the level: very small, small, medium, large and very large. Table 1 shows a three-point scale and a five-point scale.

The admissibility of occupational risk is mainly determined by the currently legal regulations and standards. However, in the absence of specific legal requirements, it is recommended that enterprises make the effort to define their own scope of acceptability of occupational risk. It is required to take into account the opinions of health and safety services and employees, as well as to draw conclusions from your own experience. 
Table 1

Classification of occupational risk on a three-level and five-level scale according to the PN-N18002: 2011 standard

\begin{tabular}{|l|c|c|c|}
\hline \multicolumn{3}{|l|}{ three-point scale } & \multicolumn{3}{l}{ The severity of the consequences } \\
\cline { 2 - 4 } $\begin{array}{l}\text { The probability of occurrence the } \\
\text { consequences of threats }\end{array}$ & SMALL & MEDIUM & LARGE \\
\hline low probability & small & small & medium \\
\hline medium probability & small & medium & large \\
\hline high probability & medium & large & large \\
\hline five-point scale & \multicolumn{3}{|c|}{ The severity of the consequences } \\
$\begin{array}{l}\text { The probability of occurrence the } \\
\text { consequences of threats }\end{array}$ & SMALL & MEDIUM & LARGE \\
\hline low probability & $\begin{array}{c}\text { very small } \\
\text { small } \\
\text { medium probability }\end{array}$ & $\begin{array}{c}\text { small } \\
\text { medium } \\
\text { large }\end{array}$ & $\begin{array}{c}\text { medium } \\
\text { large } \\
\text { very large }\end{array}$ \\
\hline high probability & \multicolumn{2}{|c|}{}
\end{tabular}

Source: (PN-N-18002:2011)

\section{THE OCCUPATIONAL RISK ASSESSMENT AT THE POSITION OF A FORKLIFT OPERATOR}

A forklift operator often works in places where heavy goods and bulky goods are transported. The type of workplace in which the forklift is used varies greatly. These can be warehouses, sales halls, production halls, as well as households where the presence of a forklift truck is essential. Employees who operate the lift trucks must have appropriate qualifications confirmed by appropriate qualification certificates. It is necessary to complete a training course, as well as comply with all regulations and rules regarding the safe performance of work. Often, when employees perform their duties, transporting loads, they have to cooperate with other employees. This is required in order to maintain the highest level of work safety (Romanowska-Słomka et al., 2009; Saja et al., 2017). Therefore, the forklift operator is required to know and follow many safety instructions, including manual transport, storage of goods or rules of internal transport. Working as a forklift driver is a very responsible job that requires the employee to be prudent and predictive. This work position is associated with a large number of risks, e.g. the possibility of being hit or crushed by the load, as well as the possibility of the truck overturning or causing harm to other people in the immediate vicinity (Chrószcz et al. 2011; Dobosz et al. 2016; Reese, 2018).

Table 2 presents the main identified hazards that occur at the workplace of a forklift operator. Table 2 also includes possible causes and effects of individual hazards, as well as actions and preventive measures.

Table 2

Threatsat the forklift operator's workplace

\begin{tabular}{|c|c|c|c|l|}
\hline No. & \multicolumn{1}{|c|}{ Risk } & \multicolumn{1}{|c|}{ hazard source } & \multicolumn{1}{c|}{ hazard effects } & \multicolumn{1}{c|}{$\begin{array}{c}\text { Actions and preventive } \\
\text { measures }\end{array}$} \\
\hline & & $\begin{array}{l}\text { Possibility of failure to } \\
\text { detect a defect or } \\
\text { improper inspection of } \\
\text { the technical condition } \\
\text { the truck, just before } \\
\text { starting work. }\end{array}$ & $\begin{array}{l}\text { Technical } \\
\text { fault forklift }\end{array}$ & $\begin{array}{l}\text { Conducting the inspection of } \\
\text { the technical condition } \\
\text { consequences. } \\
\text { should be reliable and } \\
\text { accurate, and all noticed } \\
\text { irregularities should be } \\
\text { reported to the supervisor } \\
\text { and recorded in the book of } \\
\text { daily inspections. }\end{array}$ \\
\hline
\end{tabular}




\begin{tabular}{|c|c|c|c|c|}
\hline 2. & $\begin{array}{l}\text { Exceeding } \\
\text { the speed } \\
\text { allowed for } \\
\text { the } \\
\text { movement of } \\
\text { a forklift truck }\end{array}$ & $\begin{array}{l}\text { A forklift operator } \\
\text { exceeding the travel } \\
\text { speed. }\end{array}$ & $\begin{array}{l}\text { Possibility of the } \\
\text { trolley overturning, or } \\
\text { hitting a bystander, } \\
\text { other employees. }\end{array}$ & $\begin{array}{l}\text { Conducting trainings making } \\
\text { drivers aware of the } \\
\text { consequences of not } \\
\text { complying with the rules and } \\
\text { principles of driving safety. } \\
\text { Applying penalties to people } \\
\text { who fail to comply with the } \\
\text { employer's } \\
\text { arrangements. }\end{array}$ \\
\hline 3. & $\begin{array}{l}\text { Forklift } \\
\text { overload }\end{array}$ & $\begin{array}{l}\text { Failure to adjust the } \\
\text { trolley's capacity to the } \\
\text { transported load, or } \\
\text { incorrect setting of the } \\
\text { center of gravity. }\end{array}$ & $\begin{array}{l}\text { The truck may tip } \\
\text { over or be damaged. }\end{array}$ & $\begin{array}{l}\text { Observe the operational } \\
\text { parameters of the trolley and } \\
\text { familiarize yourself with the } \\
\text { weight of the transported } \\
\text { load in advance. }\end{array}$ \\
\hline 4. & Vibration & $\begin{array}{l}\text { An employee's } \\
\text { perception of vibration } \\
\text { is affected by the } \\
\text { rigidity of the forklift } \\
\text { truck or an improperly } \\
\text { cushioned operator's } \\
\text { seat. }\end{array}$ & $\begin{array}{l}\text { Excessively felt } \\
\text { vibrations cause pain } \\
\text { effects in the } \\
\text { abdominal cavity and } \\
\text { the musculoskeletal } \\
\text { system. }\end{array}$ & $\begin{array}{l}\text { It is recommended to check } \\
\text { the cushioning of the seat } \\
\text { and the fit of the forklift } \\
\text { suspension. }\end{array}$ \\
\hline 5. & Noise & $\begin{array}{l}\text { The noise can be a } \\
\text { nuisance for employees } \\
\text { when using internal } \\
\text { combustion forklifts and } \\
\text { when working in a } \\
\text { confined space. }\end{array}$ & $\begin{array}{l}\text { The effect of } \\
\text { excessive noise can } \\
\text { damage hearing. }\end{array}$ & $\begin{array}{l}\text { In order to protect your } \\
\text { hearing against noise, use } \\
\text { ear protection and personal } \\
\text { protection. }\end{array}$ \\
\hline 6. & $\begin{array}{l}\text { Limited view } \\
\text { of the } \\
\text { operator } \\
\text { during } \\
\text { maneuvers }\end{array}$ & $\begin{array}{l}\text { Large loads can limit } \\
\text { the driver's vision and } \\
\text { make certain } \\
\text { maneuvers difficult. }\end{array}$ & $\begin{array}{l}\text { Transporting large- } \\
\text { size loads may cause } \\
\text { the driver to fatigue } \\
\text { faster. Driver fatigue } \\
\text { reduces } \\
\begin{array}{ll}\text { concentration his } \\
\text { attention. }\end{array}\end{array}$ & $\begin{array}{l}\text { During the transport of large } \\
\text { loads, special care should be } \\
\text { taken and a person to guide } \\
\text { the transport of the load } \\
\text { should be appointed. Secure } \\
\text { the work area of the truck to } \\
\text { prevent outsiders from } \\
\text { entering this dangerous } \\
\text { area.. }\end{array}$ \\
\hline 7. & $\begin{array}{l}\text { Incorrect } \\
\text { arrangement } \\
\text { of the load on } \\
\text { the forklift }\end{array}$ & $\begin{array}{l}\text { Incorrect arrangement } \\
\text { of the load on the } \\
\text { forklift truck, incorrectly } \\
\text { defined center of } \\
\text { gravity. }\end{array}$ & $\begin{array}{l}\text { Possibility of the load } \\
\text { tipping over, or } \\
\text { of the entire load cart. } \\
\text { The driver may be } \\
\text { disabled or killed as a } \\
\text { result of the accident. }\end{array}$ & $\begin{array}{l}\text { The load must be properly } \\
\text { arranged on the forklift with } \\
\text { special care and taking into } \\
\text { account the rules of the } \\
\text { goods storage instructions. }\end{array}$ \\
\hline
\end{tabular}

Source: Own study

Most of the accidents occurring with the participation of lift trucks are related to the excessive speed of the device, insufficient range of vision about the surroundings by the operator. The effects of such accidents are hitting pedestrians, collisions with other forklifts, as well as collisions with infrastructure. To prevent the consequences of such collisions from being fatal or very serious, all kinds of preventive measures should be applied.

\section{STATISTICAL DATA OF THE OFFICE OF TECHNICAL INSPECTION}

The use of forklifts in in-house transport is associated with the possibility of accidents. The consequences of accidents are serious injuries and fatalities. In his duty, the employer must analyze the causes and effects of accidents involving forklifts. This analysis is a support point for occupational risk management, as well as helps to identify areas requiring action to improve the safety of equipment operation. The register of dangerous accidents and its analysis allow you to pay attention to their nature and type. Often, people injured in potentially dangerous accidents are divided into two groups: they are forklift operators and bystanders. The number of people 
injured in such accidents has a growing tendency in recent years. This is due to the increasing popularity of this type of device in enterprises. The dynamically developing trade, transport and distribution networks have imposed a wide application of these devices, which are one of the easiest means used to move relatively heavy loads.

The analysis of statistical data was carried out on the basis of data obtained from the Office of Technical Inspection. This analysis is based on data relating to the years 2013-2017, in which the relationships between the safe operation of devices and the proper conduct and compliance with the provisions of the rules by employees were examined.

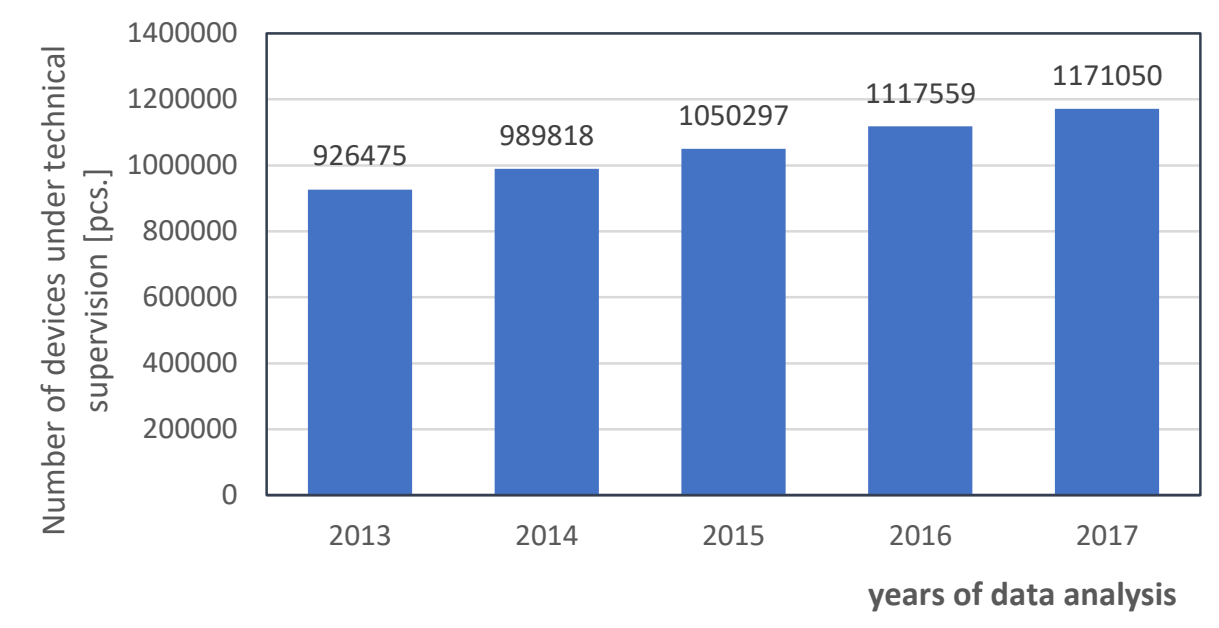

Fig. 1. Number of technical devices under the supervision of the technical inspection office, to a full and limited extent in 2013-2017

Figure 1 shows the number of all technical devices that are subject to full technical supervision and limited technical supervision in 2013-2017. According to the data obtained, this number showed an upward trend over the period of 5 years. During these years, the number of devices increased by 244,575 units, and on average $1,051,040$ additional devices registered per year. This proves that it is highly probable that in the coming years the number of devices that are subject to technical supervision will continue to increase. The number of devices subject to technical inspection (Fig. 1) applies only to devices registered in the Office of Technical Inspection, one should also remember about the presence of devices that have not been registered in the UDT office or are not subject to its supervision.

The number of revealed dangerous failures in 2013-2017 is shown in Figure 2. This figure shows the total number of registered dangerous failures of all devices subject to full technical supervision and limited technical supervision as well as the number of registered dangerous failures of handling equipment. In the analyzed period of recorded values, we note that the numbers for damage to all devices are relatively similar, except for 2014, when the number of 84 dangerous failures was recorded. On the other hand, in the case of revealed dangerous failures of transport equipment close to the number of these values, there is a slight difference, with the exception of 2014, when 62 such events were registered. The average number of dangerous failures of technical devices in 2013-2017 is 99 events. 


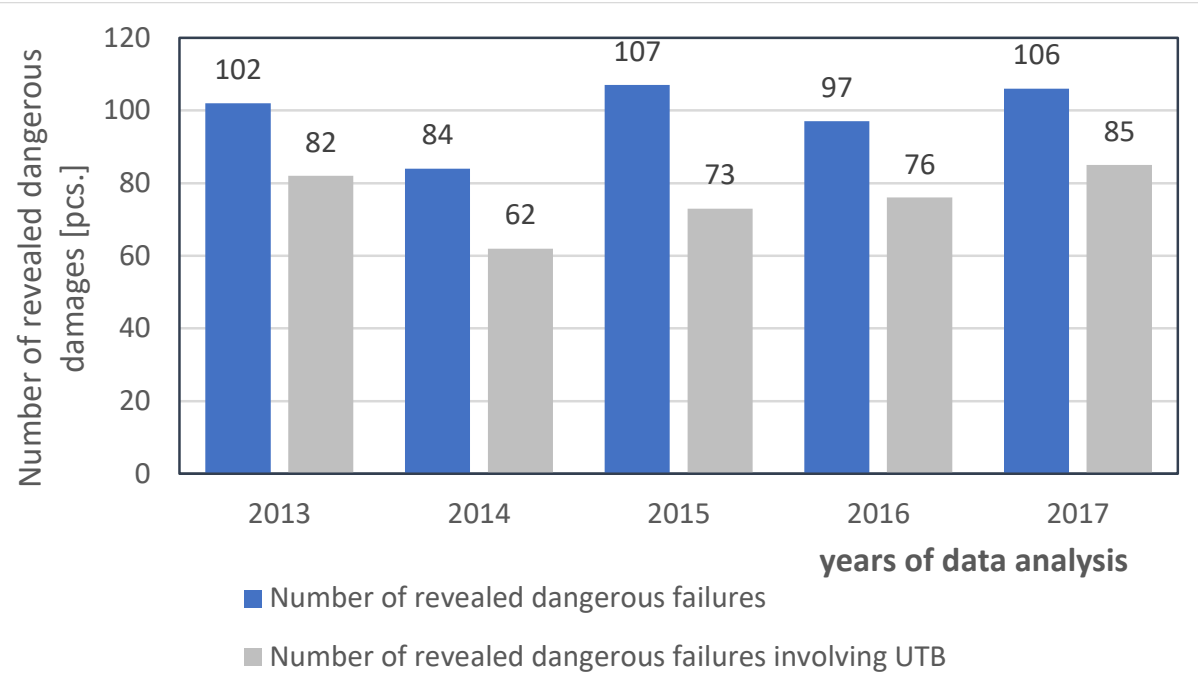

Fig. 2. Number of revealed dangerous failures of technical devices in 2013-2017

The number of fatalities and people with injuries as a result of an accident involving a forklift truck in 2013-2017 is shown in Figure 3. In 2013 and 2015, there were no fatalities as a result of an accident involving a forklift truck, in the remaining analyzed years the same value was nearly five. However, in the case of people injured, including bodily injuries in 2013 and 2014, it is close to each other, and amounts to 5 and 6 victims, respectively. In 2015-2017, there was a significant increase in the number of people injured in accidents related to the participation of a forklift truck. In 2016, the highest number of 28 people with injuries was recorded.

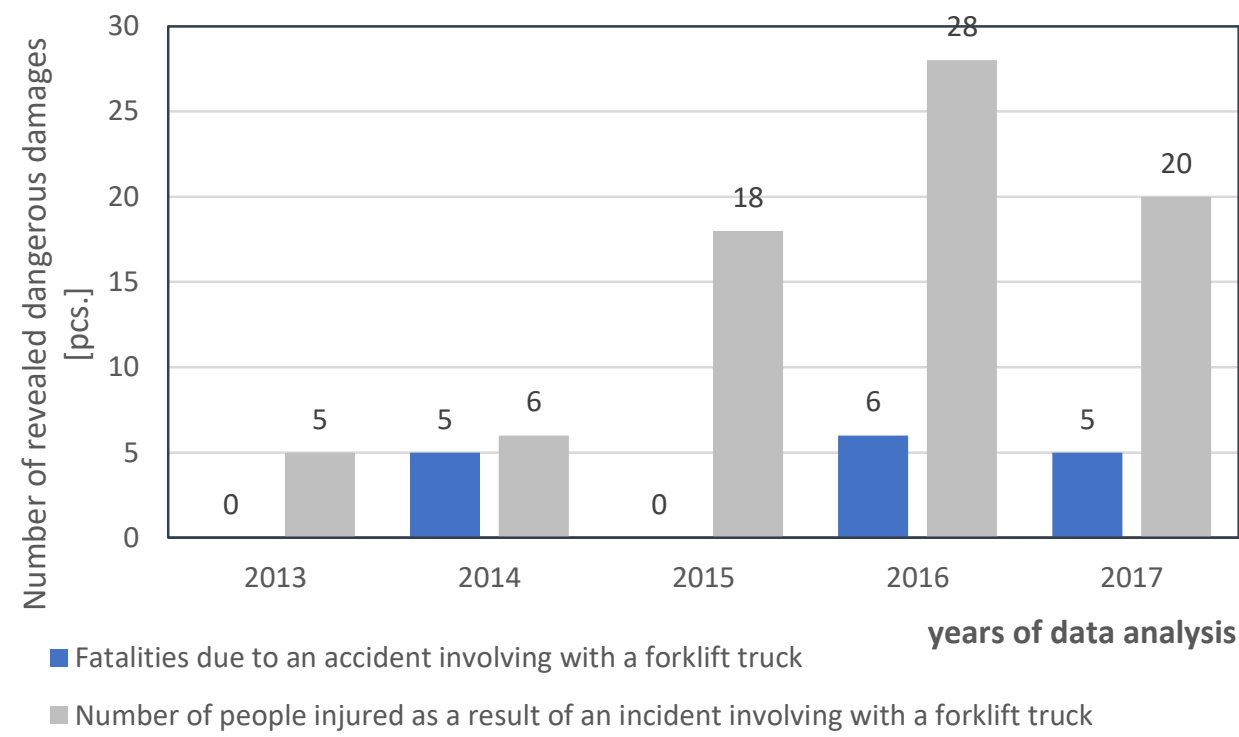

Fig. 3. Number of fatalities and victims of accidents at work involving a forklift truck in 2013 2017

The causes of accidents and dangerous incidents involving lift trucks are shown in Figure 4. These causes have been appropriately grouped. Classification the causes of accidents involving forklifts is: 
- design defects,

- technological defects,

- operational errors.

The presented data show that the most common causes of accidents with the participation of forklift trucks in 2015-2017 were operational defects, the results of which are the highest value among other qualifications of the causes of accidents. This result reaches nearly $100 \%$ of the causes of unwanted accidents. Successively, technological defects and design defects find their place, the percentage of which is within $8 \%$. Other causes of accidents or dangerous activities, such as corrosion and wear, material defects and damage to accessories, were not marked in Figure 4, because in the analyzed years no such causes of hazardous events were recorded..

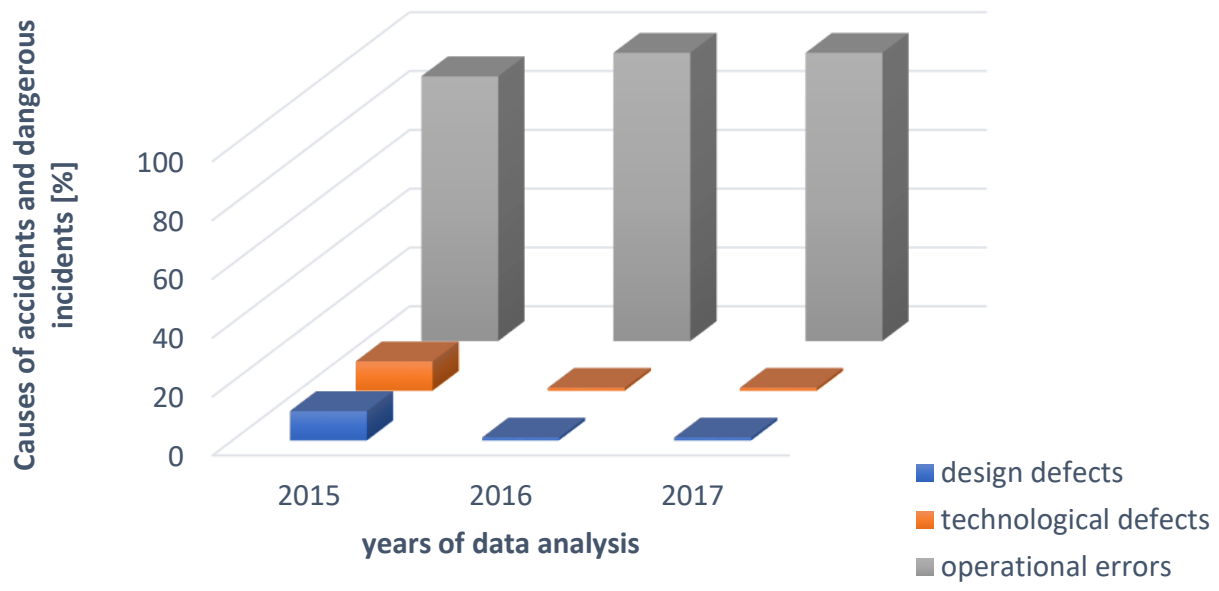

Fig. 4. The causes of accidents and dangerous incidents in 2015-2017

Based on the analysis of statistical data for the period 2013-2017, the number of all technical devices registered with the Office of Technical Inspection, which consists of pressure equipment and handling equipment, increased and, as the analyzes show, the number will continue to grow. Unfortunately, the number of fatalities and the number of victims with personal injuries are also increasing. Sometimes the injuries are so serious that they eliminate the worker from further work.

From the presented graphs it can be concluded that the handling equipment is characterized by a higher degree of risk compared to pressure equipment. As shown in Figure 4, operational defects have the greatest share in the contribution of accidents and hazardous events. These disadvantages are mainly the lack of appropriate qualifications of the operators, as well as the employees' failure to comply with the rules and regulations of safe work and failure to adapt their behavior to the conditions contained in the technical and operational documentation of the device. Regular inspections, maintenance and repairs by appropriately qualified persons also play a special role in avoiding undesirable events. Performing these activities directly affects the proper maintenance of the technical condition of the device, and thus increases the level of safety and avoiding dangerous events. Proper operation is also a factor reducing the risk of failures, which are a threat to the health and life of the operator of the technical device and bystanders in the area of operation of the device. 


\section{SUMMARY}

During the operation of lift trucks, there are a number of dangers that may result in accidents or dangerous events affecting the health of employees and bystanders. From the hazard identification and occupational risk assessment carried out in accordance with the matrix method, it is concluded that high occupational risk is related to, among others:with the non-compliance with the forklift speed limits that are allowed. This risk may cause the truck to overturn or run over by a bystander. A big risk is also overloading the forklift, which can also lead to the truck turning over or damaged. Another risk is also damage to the rack structure in the warehouse, which may result in the death of an employee staying near the rack and material losses. Driving a forklift on a slippery and uneven surface is also a high risk, which may result in the loss of control by the driver. The group of medium-risk hazards includes, among others: incorrect positioning of the load on a forklift truck, hits by falling objects, the physical load of the employee and noise that affects the human body. These threats result in the uncontrolled fall of the load, fatigue of the employee, and thus a decrease in his concentration and attention. Lowered concentration and inattention of the employee is a direct factor that significantly increases the risk of accidents involving forklifts. The group of low-risk hazards includes, among others: vibrations generated by the device and changing weather conditions. The effects of this group of threats are pain in the abdominal cavity, the musculoskeletal system as well as faster fatigue and diseases.

In order to counteract the dangers occurring at the position of a forklift truck operator, it is necessary to carry out periodically repeated occupational risk assessment. This assessment provides the employer and managers with information about the existing threats, as well as supports the constant undertaking of actions and activities aimed at eliminating or reducing occupational risk at the workplace. These activities are also to lead to a constant search for new activities, the implementation of which is to protect employees against accidents and dangerous incidents..

\section{REFERENCES}

Brown, K.R., Hastie, M., Khan, F.I., Amyotte, P.R. 2021. Inherently safer design protocol for process hazard analysis, Process Safety and Environmental Protection, 149, 199-211, DOI: 10.1016/j.psep.2020.10.046

Chrószcz B., Hansel J., 2011. Analiza i ocena ryzyka zawodowego, Wydawnictwa AGH, Kraków.

Dane uzyskane z Urzędu Dozoru Technicznego (listopad 2017 r.).

Dobosz, M., Saja, P., Pacana, A., Woźny, A., 2016. Improvement of health and safety conditions at selected workplaces - on the example of transhipment terminal logistics company, Production Management and Engineering Sciences, London, 55-59.

Jabłoński, A., Jabłoński, M. 2014. Ryzyko techniczne i zawodowe w transporcie kolejowym - kluczowe aspekty integracji, TTS Technika Transportu Szynowego R. 21, 2014, 9, 31-35.

Kapustka, K., Ziegmann, G., Klimecka-Tatar, D., Ostrega, M., 2020. Identification of health risks from harmful chemical agents-review concerning bisphenol $A$ in workplace, Production Engineering Archives, 26 (2), 45-49, DOI: /10.30657/pea.2020.26.10 
Klimecka-Tatar, D., Niciejewska, M., 2016. The OSH management system in the "small-sized" production company, Production Engineering Archives,13 (4), 49-52, DOI: 10.30657/pea.2016.13.11

Koradecka, D., 2008. Bezpieczeństwo i higiena pracy, Wyd. CIOP-PIB, Warszawa (in Polish).

Matuszewska, E., Orwat, J., 2016. Professional risk assessment on the workplace of surface surveyor employed in measuring-geological department of coalmine, Management Systems in Production Engineering, 6(2), 123-127.

Polska Norma PN-N-18002:2011: Systemy zarządzania bezpieczeństwem i higieną pracy. Ogólne wytyczne oceny ryzyka zawodowego.

Prochowski, L., Żuchowski A. 2009: Technika transportu ładunków. Wydawnictwa Komunikacji i Łączności, Warszawa, 314.

Rączkowski, B., 2020. BHP w praktyce, Wyd. ODDK, Gdańsk.

Reese, C.D., 2018. Occupational health and safety management: a practical approach, CRC Press.

Romanowska-Słomka, I., Słomka, A. 2008: Zarządzanie ryzykiem zawodowym. Wydanie VI. Wydawnictwo Tarbonus, Kraków-Tarnobrzeg, 120.

Romanowska-Słomka I., Słomka A., 2009. Zarządzanie ryzykiem zawodowym, Tarbonus, Kraków-Tarnobrzeg.

Saja, P., Woźny, A., Pacana, A., Dobosz, M., 2017. Additional components of risk assessment and their impact on the probability parameter, Production Engineering Archives, 14, 11-14, DOI: 10.30657/pea.2017.14.03

Szlązak, J., Szlązak, N., 2010. Bezpieczeństwo i higiena pracy, Wyd. AGH, Kraków.

Ulewicz, R., Mazur, M., Klimecka-Tatar, D., Niciejewska, M., 2015. Wybrane aspekty zarządzania bezpieczeństwem i higiena pracy, Wyd. SMJiP, Częstochowa (in Polish).

Woźny, A. 2020. Selected problems of managing work safety - case study. Production Engineering Archives 2020, 26 (3), 99-103. DOI: 10.30657/pea.2020.26.20

Woźny, A., Dobosz, M., Saja, P., Pacana, A., 2015. Ryzyko zawodowe ryzykiem fiaska innowacyjnej działalności sektora MSP, Zeszyty Naukowe Politechniki Częstochowskiej, Zarządzanie, 19, 75-88. 